\title{
環状オリゴ糖の化学合成一シクロアワオドリンの創製—
}

\author{
西 沢 麦 夫*
}

\section{Synthesis of Cyclooligosaccharides and Creation of $\alpha$-Cycloawaodorin}

Mugio NishizawA*

\begin{abstract}
Significant attentions have been focused on the inclusion chemistry of cyclodextrins and the related compounds, and synthetic studies of cyclooligosaccharides have been carring out intensively. For example, Ogawa and coworkers reported the total synthesis of cyclodextrins and a manno isomer of cyclodextrins by means of phenylselenyl triflate promoted cycloglycosylations. Synthesis of $1-3 \beta$ linked cycloglucohexaose was reported by Collins' group. Modifications of $\alpha$-cyclodextrin into trimethyl, 1,3-anhydro, and a chimera analog have also reported recently. However, cyclooligosaccharide available today is only limited to D series. As we have developed a novel thermal glycosylation procedure, which can be applied to rhamnosylation with high $\alpha$-selectivity, we designed the synthesis of cyclo-L-rhamnohexaose (40), the first cyclooligosaccharide of L series. On the basis of the area where the compound has been prepared, this compound was named $\alpha$-cycloawaodorin, which would open a new dimension of the inclusion chemistry .
\end{abstract}

Key words : Cyclooligosaccharide; Cyclodextrin ; Cyclo-L-rhamnohexaose; $\alpha$-Cycloawaodorin ; Glycosylation ; Thermal glycosylation; Inclusion chemistry; Synthesis.

\section{1.はじめに}

環状オリゴ糖を代表するシクロデキストリンは， Dグルコピラノースが $\alpha-1,4-$ 結合して構成される環状才 リゴ糖で，それを構成するグルコース単位の数によって $\alpha(6$ 単位 $)(1), \beta$ (7 単位) ( 2$), \gamma$ (8 単位) ( 3 ) と命名 されている。これらはデンプンにBacillus macerans のア ミラーゼを作用させることにより生成する。シクロデキ ストリンはその中央にある空洞内にさまざまな分子を取 り込み包接する能力を有しており，いわゆるホスト分子 として, あるいは酵素モデルとして, 大きな期待を集め, その構造, コンフォメーション，さまざまな包接化合物 の作成, 触媒反応の開発等, 広範囲な研究の対象となっ ている ${ }^{1 \sim 6)}$ 。そして不安定医薬品の安定化や, 非水溶性 医薬品の可溶化, 揮発性物質の固定化等産業界でも大活 躍を見せ始めている。最近ではプロスタグランジン $\mathrm{E}_{2}$

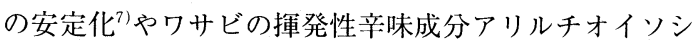
アネートの固定化等 ${ }^{8)}$ が話題を呼んでいる。

* 徳島文理大学薬学部

* Faculty of Pharmaceutical Sciences, Tokushima Bunri University
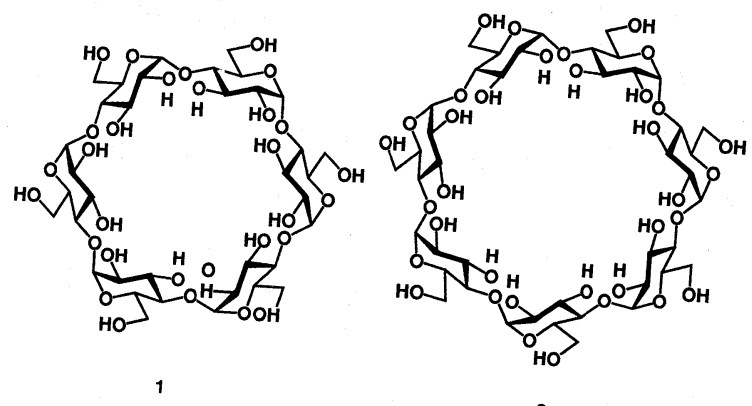

2

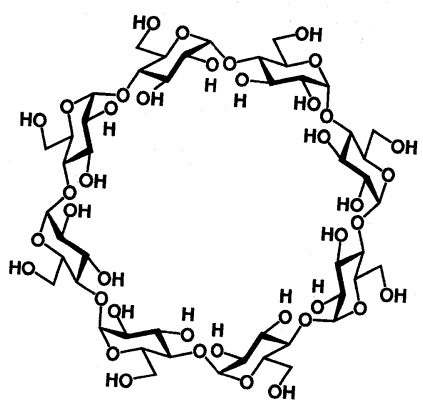

3

Fig. 1 


\section{2. 環状オリゴ糖の化学合成}

本稿では有機合成の立場から，環状オリゴ糖の化学を 概観してみようと思う。1985 年に $\alpha$-シクロデキストリ ン( 1 )の初めての全合成を報告して，この分野の口火を 切ったのは, 糖の合成化学において, 膨大な業績を挙げ ている小川智也教授のグループである。小川等は， $\mathrm{D}^{-}$グ ルコースの $\alpha-1,4$-二量体であるマルトースを原料に 4 と 5 を導いてその縮合を行い四量体を合成し，ついで四 量体と二量体 4 の縮合で六量体を合成した。各グリコシ ル化反応にはフッ素糖を塩化第一スズ/銀トリフラート で活性化する向山法が採用され，4 と 5 の縮合では収率 $79 \%$ で四量体が生成し，1.8：1でより多く生成する $\alpha-$ 体 6 を分離しながら合成を進めている。最終工程の環化 グリコシル化反応にも向山法が使われ，7を $21 \%$ の収 率で環化させ，Pd 触媒による水素化反応で保護基を除 去し, 初めての環状オリゴ糖 1 の全合成が達成され た ${ }^{910)}$ 。また同様な手法で $\gamma$-シクロデキストリン $(3)$ の 全合成にも成功している"1)。

小川らが次に狙ったのは，非天然系の環状オリゴ糖の 合成で, D-マンノースを素材にシクロ-Dーマンノへキサ オース(12)を全合成した。ここで小川らはトリクロロメ チルイミデートを脱離基に用いるグリコシル化反応一 Schmidt 法一を糖鎖延長の基本手段に採用し，モノマー 8 と 9 の縮合で $\alpha$-選択的に二量体 10 を導き，さらに 8 を縮合させて三量体，そして三量体同士の縮合という ルートにより， $\mathrm{D}$-マンノースの $\alpha$-六量体を合成してい る。環化グリコシル化反応は六量体 $\omega$-ヒドロキシ- $S-$ メチル糖 11 をェニルセレニルトリフラート $(\mathrm{PhSeO}-$ Tf)で活性化する方法を工夫し，64\% という高い収率で

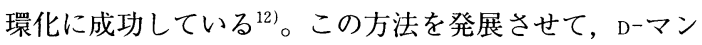

ノースの環状七糖体 13 ，八糖体 14 の合成に成功すると ともに ${ }^{13)}$, D-マンノース環状六糖体の長鎖エーテル誘導 体 15 の合成などを報告している ${ }^{14)}$

イギリスの Collins らはAgOTfを用い，2 位ベンゾイ ル基による隣接基関与を活用した, 臭化糖 16 とアルコー ル 17 の立体選択的な Koenigs-Knorr 反応で二糖体 18 を 合成した。1 18 のベンジリデン基は $\mathrm{BrCCl}_{3}$ 存在下に光照

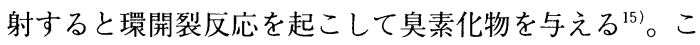
れを $\alpha-\mathrm{Br}$ 体に異性化させて19を導いた後，同じ反応 を繰り返して，ヘキサマー20を導いた。20をAgOTf による環化反応に付し，ユニークな $1,3-\beta$-リンクのシ クロデキストリン類縁体 21 を合成した ${ }^{16)}$ 。

フランスの Driguez らはシクロデキストリングルコシ ルトランスフェラーゼ(CGTase)を活用した, フッ化マ ルトーズ 22 の重合環化反応を検討し，43\%の収率で $6^{\mathrm{A}}, 6^{\mathrm{B}}, 6^{\mathrm{C}}$-トリーO-メチルシクロマルトヘキサオース (23) を与える条件を見いだした。化学合成に比べて効率が高 いことを自慢している ${ }^{17)} 。$

環状オリゴ糖を全合成する研究と別に, 市販のシクロ デキストリンそのものを原料にして，さまざまな人工類 縁体を合成して，その包接能をみようという研究が数限 りなく行われている。ここでは, 最近の合成化学的にも 興味深い，二例を紹介したい。1つは葛原らが報告した キメラ体 24 の例で, 一旦 $\alpha$-シクロデキストリンを選択 的に一点開裂させ， $N$-アセチル-D-グルコサミンを埋め 込んで再閉環させたもので, $\beta$-シクロデキストリンの 2 位水酸基の一箇所を $\mathrm{NHAc}$ 基に置換したことに相当 する興味深い化合物である ${ }^{18)}$ 。25 はフランスの Defaye およびイギリスの Stoddart の 2 つのグループがほほ同 時に発表した化合物で，シクロデキストリンの 6 位水酸 基を選択的にトシル化した後，3,6位で環をまかせなが

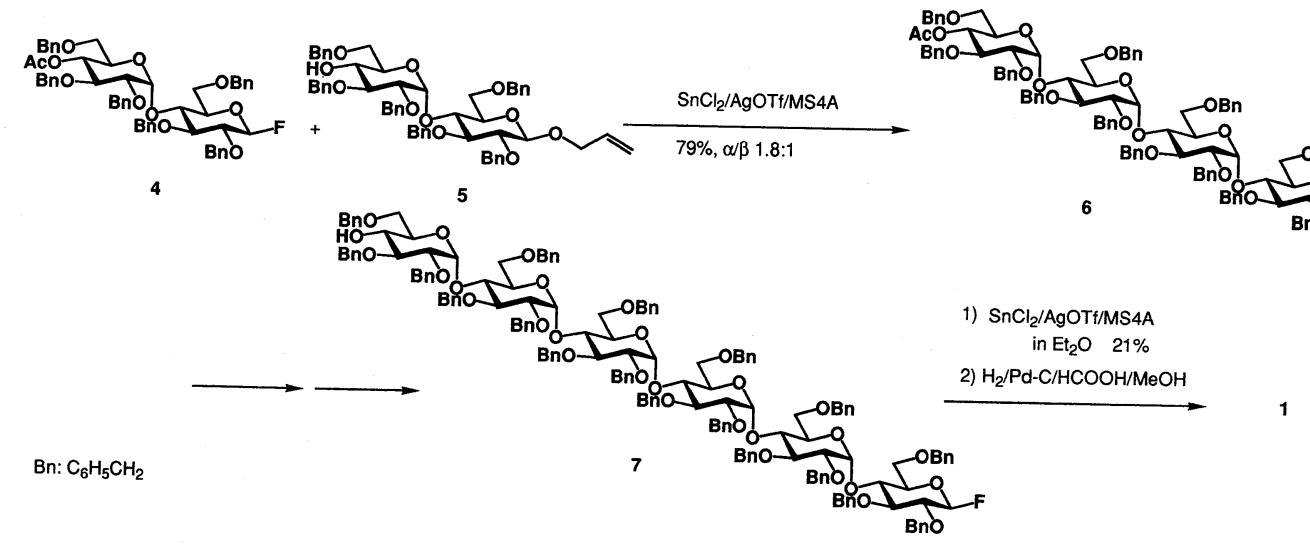

Fig. 2 

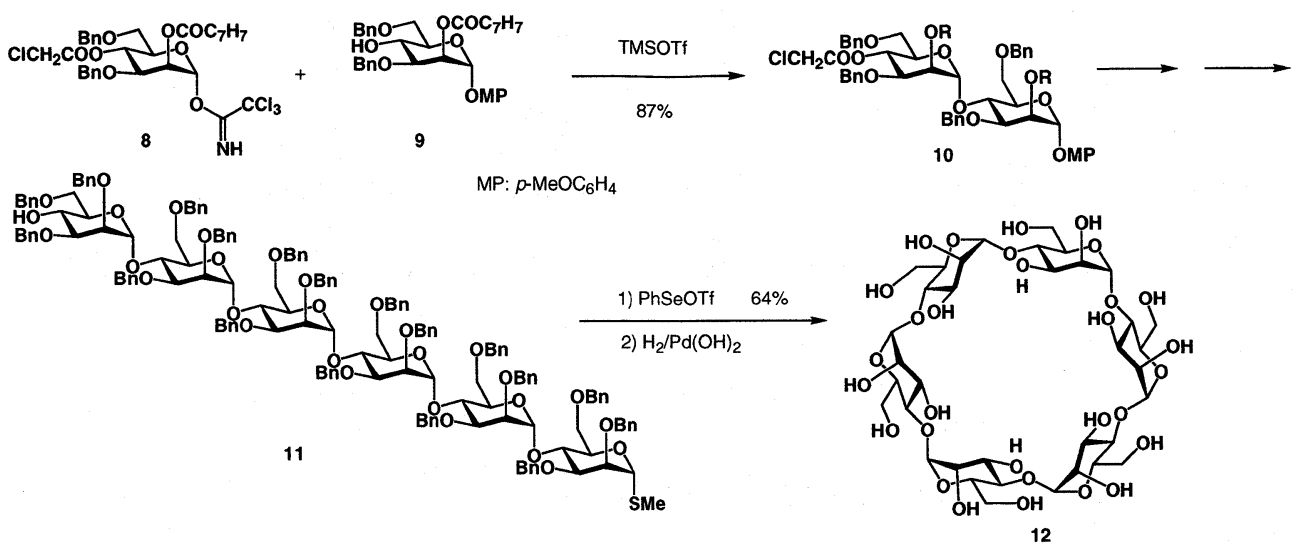

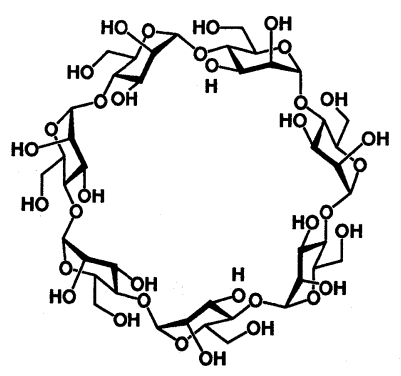

13

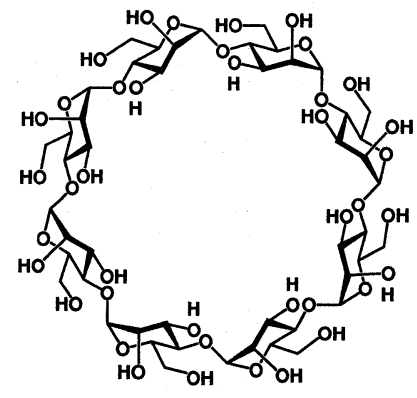

14

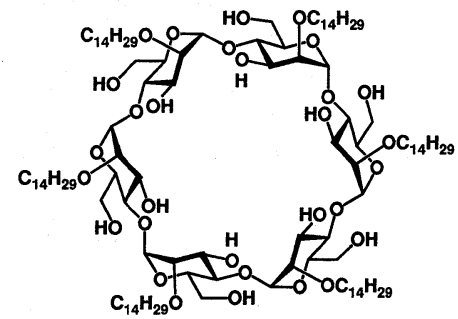

15

Fig. 3

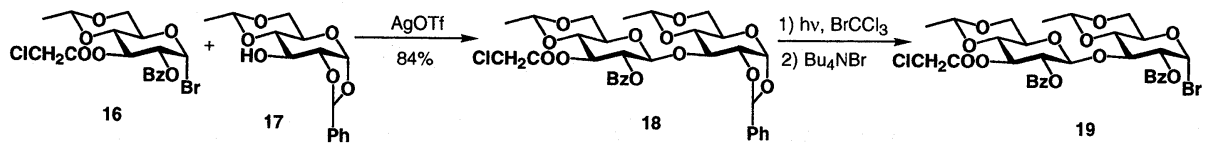

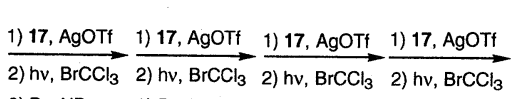
3) $\mathrm{Bu}_{4} \mathrm{NBr}$ 3) $\mathrm{Bu}_{4} \mathrm{NBr}$ 3) $\mathrm{Bu}_{4} \mathrm{NBr}$

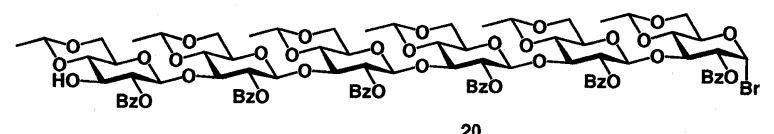

20

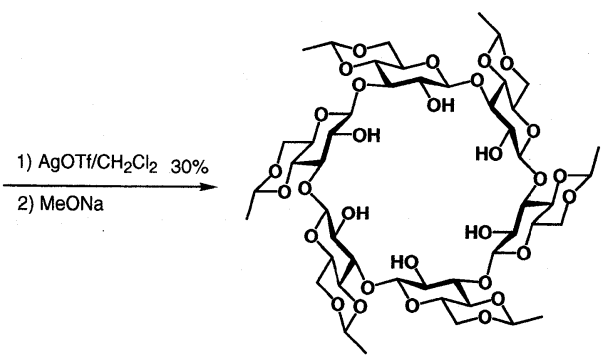

Fig. 4 


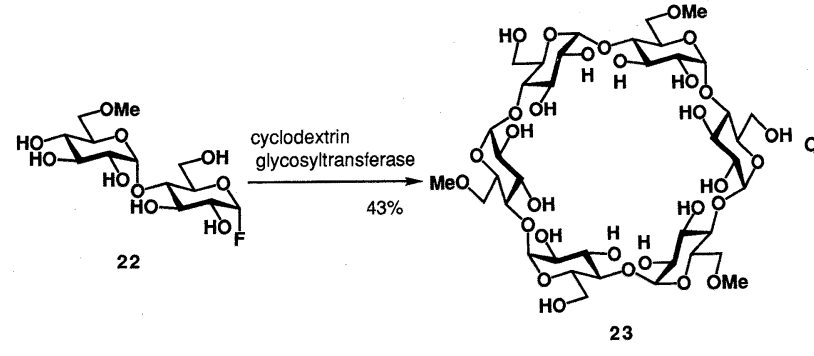

Fig. 5

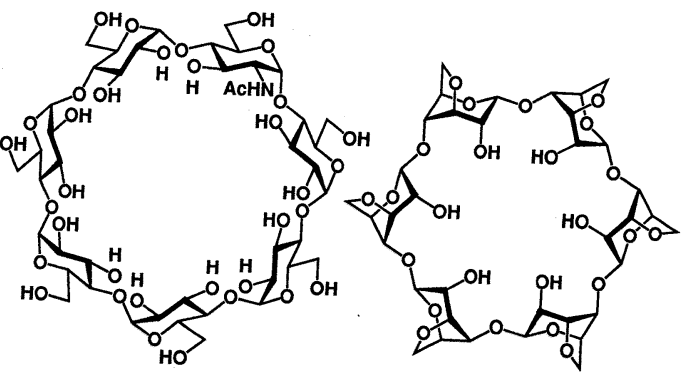

24

25

Fig. 6

ら，六個のピラン環をすべて反転させてしまった化合物 である ${ }^{19,20)}$ 。

\section{3. グリコシル化反応の発展と熱グリコシル化 反応の開発}

環状オリゴ糖の合成が相次いで報告されるに至った背 景には，糖と糖をつなぐ反応一グリコシル化反応一の長 足の進歩が潜んでいる。先に登場した銀塩や水銀塩を大 量に使用するグリコシル化反応の原点 Koenigs-Knorr 法 ${ }^{21,22)}$ に続いて, フッ素糖を $\mathrm{SnCl}_{2}$ と $\mathrm{AgOTf}$ で活性化す る向山法 ${ }^{23)}$, トリクロロメチルイミデートを脱離基とす るSchmidt 法 ${ }^{24)}$ ，小川らの PhSeOTf で $\mathrm{S}$ 糖を活性化す る方法等 ${ }^{25)}$ ，環状オリゴ糖の合成に活躍した方法のほか にも，やはりフッ素とシリコンの特別な親和性を活用す る野依法 ${ }^{26)}$, フッ素糖を $\mathrm{Cp}_{2} \mathrm{HfCl}_{2}$ および $\mathrm{AgOTf} て ゙$ 活性 化する鈴木法 27)，さらにFraiser-Reid によるペンテニル グリコシドの活用法 ${ }^{28)}$, Nicolaou らによるチオグリコシ ドの NBS による活性化法 ${ }^{29)}$, 池上, 橋本らのリン酸エ ステルの活用法 ${ }^{30)}$, Kahne らのスルホキシドを無水トリ フラートで活性化する方法 ${ }^{31)}$, Danishefsky らのグルカー ルをヨードニウムイオンで活性化する方法 ${ }^{32}$, ならびに アンヒドロ糖の利用法 ${ }^{33)}$, Ley らのイミダゾイルカルボ ニル基を脱離基とする方法 ${ }^{34)}$ ，2-ピリジンカルボキシ レートを脱離基とする小林らの方法 ${ }^{35)}$ な゙が最近のめぼ しい進歩である。これらは, 最近の優れた総説に詳し $w^{36-38)}$ 。

さて私達は超甘味配糖体の全合成を計画して, ジテル ペン配糖体のバイユノシド(26)や や $^{39 ~ 43)}$ ステロイド配糖体 オスラジン $(27)^{44,45)}$ の全合成を行い, 甘味と化学構造の 多様性に感じ入りながらグリコシル化反応の世界に足を 踏み入れる結果になった。

糖の合成化学という分野は, 各研究者がこぞって独自 のグリコシル化反応を案出し，その上に独自の合成化学 を展開するという風潮の世界で, 私達はなんらかのオリ
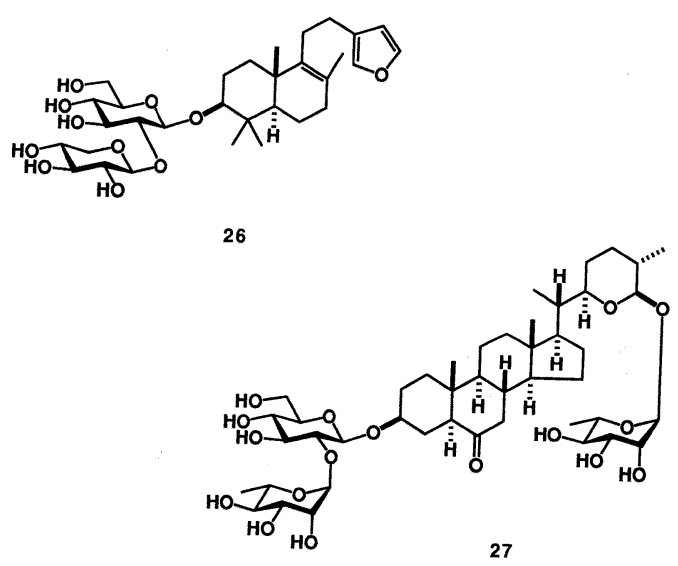

Fig. 7

ジナリティーを求めて工夫する必要に迫られた。先に述 ベたように，最近発表されているグリコシル化反応の多 くはアノマー位の脱離基に工夫をこらして独自性が競わ れている。私達は離れていく部分は一番当たり前の塩素 一本に絞り, 反応条件をさまざまに検討した。その結果， 一切の金属塩を用いることなく，溶媒もない状態で，八 ロゲン化糖とアルコールの縮合が熱のみで達成できるこ とを見いだした。塩化糖としてはこれまで，グルコース 誘導体 28, 29, キシロース誘導体 30, マンノース誘導 体 31, ラムノース誘導体 32, および $N$-アセチルグル

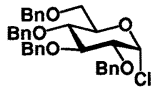

28

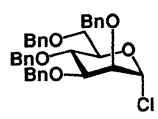

31

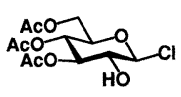

29

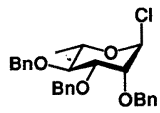

32

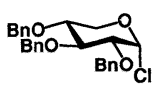

30

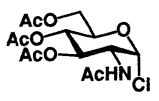

33
Fig. 8 
Table 1 熱グリコシル化反応

\begin{tabular}{rccccccc}
\hline run & Chloride & Alcohol & Acid Scavenger & Temperature $\left({ }^{\circ} \mathrm{C}\right)$ & Time (h) & Yield $(\%)$ & $\alpha / \beta$ ratio \\
\hline 1 & $\mathbf{2 8}$ & $\mathbf{3 4}$ & TMU & 120 & 4 & 92 & $60: 40$ \\
2 & $\mathbf{2 8}$ & decanol & TMU & 120 & 2 & 69 & $74: 26$ \\
3 & $\mathbf{2 8}$ & geraniol & TMU & 120 & 2 & 94 & $71: 29$ \\
4 & $\mathbf{2 8}$ & $\mathbf{3 5}$ & TMU & 140 & 2 & 39 & $40: 60$ \\
5 & $\mathbf{2 8}$ & $\mathbf{3 6}$ & TMU & 120 & 8 & 55 & $59: 41$ \\
6 & $\mathbf{2 9}$ & $\mathbf{3 4}$ & TMU & 110 & 2 & 73 & $52: 48$ \\
7 & $\mathbf{3 0}$ & $\mathbf{3 4}$ & TMU & 120 & 3 & 64 & $45: 55$ \\
8 & $\mathbf{3 0}$ & geraniol & TMU & 120 & 2 & 54 & $63: 37$ \\
9 & $\mathbf{3 1}$ & $\mathbf{3 4}$ & TMU & 140 & 0.75 & 79 & $87: 13$ \\
10 & $\mathbf{3 1}$ & $\mathbf{3 8}$ & -- & 140 & 0.5 & 80 & $100: 0$ \\
11 & $\mathbf{3 2}$ & $\mathbf{3 4}$ & TMU & 140 & 0.5 & 89 & $93: 7$ \\
12 & $\mathbf{3 2}$ & $\mathbf{3 5}$ & -- & 140 & 0.5 & 99 & $87: 13$ \\
13 & $\mathbf{3 2}$ & $\mathbf{3 6}$ & -- & 140 & 1 & 48 & $100: 0$ \\
14 & $\mathbf{3 2}$ & $\mathbf{3 7}$ & -- & 140 & 0.75 & 74 & $100: 0$ \\
15 & $\mathbf{3 2}$ & $\mathbf{3 8}$ & -- & 140 & 0.5 & 55 & $100: 0$ \\
16 & $\mathbf{3 2}$ & $\mathbf{3 9}$ & -- & 140 & 0.5 & 65 & $100: 0$ \\
17 & $\mathbf{3 3}$ & $\mathbf{3 4}$ & TMU & 60 & 72 & 82 & $6: 94$ \\
18 & $\mathbf{3 3}$ & $\mathbf{3 4}$ & TMU & 180 & 0.25 & 46 & $83: 17$ \\
19 & $\mathbf{3 3}$ & $\mathbf{3 4}$ & $\alpha-M S$ & 60 & 21 & 95 & $5: 95$ \\
20 & $\mathbf{3 3}$ & $\mathbf{3 4}$ & $\alpha-M S$ & 160 & 0.3 & 64 & $88: 12$ \\
21 & $\mathbf{3 3}$ & $\mathbf{3 8}$ & TMU & 60 & 10 & 86 & $7: 93$ \\
22 & $\mathbf{3 3}$ & $\mathbf{3 8}$ & TMU & 160 & 1 & 37 & $83: 17$ \\
23 & $\mathbf{3 3}$ & $\mathbf{3 8}$ & $\alpha-M S$ & 60 & 10 & 95 & $3: 97$ \\
24 & $\mathbf{3 3}$ & $\mathbf{3 8}$ & $\alpha-M S$ & 160 & 0.17 & 32 & $96: 4$ \\
\hline
\end{tabular}

TMU: N, N, N', N'-Tetramethylurea $\quad \alpha$-MS: $\alpha$-Methylstyrene

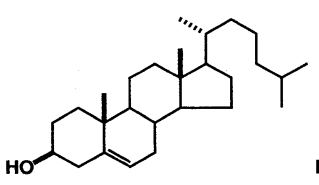

34

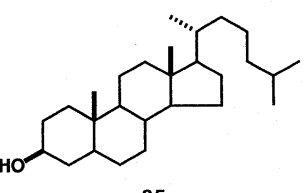

35

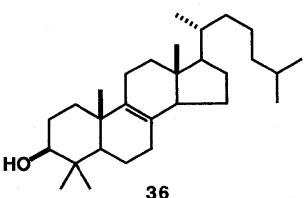

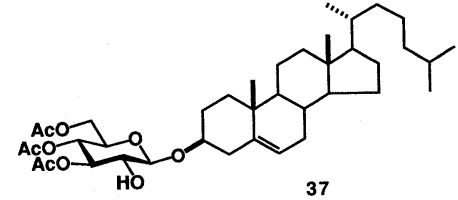

37

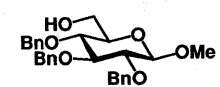

38

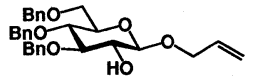

39

Fig. 9

コサミン誘導体 33 を用いて，コレステロール(34)を始 めさまざまなアルコール類 35-39に対するグリコシル化 反応を検討した ${ }^{46,47)}$ 。これらのうちで 28, 29, 30 の反応 は本質的に非立体選択的であるが(run 1〜8)，2'位にア キシャル配位の酸素置換基を有するマンノース誘導体 31 およびラムノース誘導体 32 の熱グリコシル化反応は 高 $\alpha$-選択的に進行することを明らかにした ${ }^{48)}$ (run 9〜 16)。また，グルコサミン誘導体の 33 の場合, 反応温度 に依存した興味深い立体選択性が観測された。すなわち， 比較的低温で長時間の反応を行うと, 高い $\beta$-選択性が, 高温で短時間反応させることにより高い $\alpha$-選択性が認
められた ${ }^{49)}($ run $17 〜 24) 。$

\section{4. シクロアワオドリンの創製}

この手法はとくにラムノシル化やマンノシル化反応の 場合に高 $\alpha$-選択的に反応が進行することから実用的で ある。そこで，このきわめて簡便なグリコシル化反応の 特質を発揮しうる合成ターゲットとして，L-系列環状オ リゴ糖を想定した。先に述べたようにシクロデキストリ ンによせる関心は世界的に非常に高く，今後もますます 多様な分子設計が展開されていくことであろう。しかし, 現在までに登場した環状オリゴ糖 1，2，3，12，13，14， 
$15,21,23,24$ ，および 25 は全て $\mathrm{D}$-系列の糖のみにより 構成されており，L-系列の環状オリゴ糖が存在した形跡 は全く見当たらない。未知の L-系列環状オリゴ糖を作 り出すことによって, 新しい包接の化学が開かれるので はあるまいか。私達はこの一点に着目し，L-ラムノース 同士の $\alpha-1,4$-結合を私達の熱グリコシル化反応を活用 して高選択的に形成してゆき, 初めての L-系列の環状 オリゴ糖の創製をもくろむことになった。すなわちシク ローレ-ラムノヘキサオース(40)の全合成が当面の目標で ある。

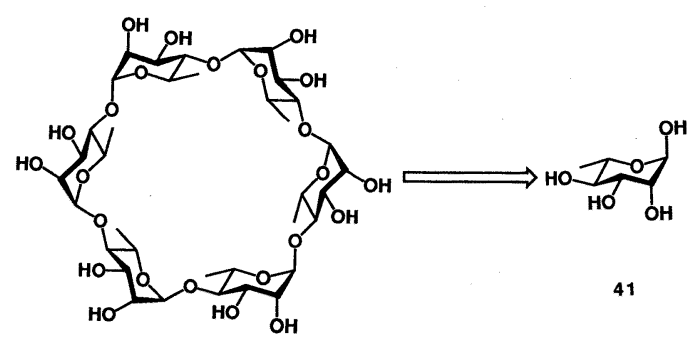

40

Fig. 10

多糖体の合成はまず単糖の水酸基の選択的保護から始 まる。モノマーアルコール44, およびモノマー塩化物 47 を次に示した一連の経路で合成した。41 から 3 工程 で得られるベンジリデン体 42 の DIBAL-H 還元では 2ヒドロキシ体と 3 -ヒドロキシ体の $4: 6$ 混合物を生じ, おのおの分離して構造を確認したが，合成反応としては 混合物のまま次のベンジル化反応に付して, ジベンジル エーテル 43 を高収率に導いた。脱保護して得た 44 がグ リコシル化反応に用いるモノマーアルコール体である。 アセチル化して水酸基を保護し 45, ついでアノマー位 のアリル保護基を除去して 46 とした。このときオレフィ
ンの異性化と酸化加水分解の二段階反応を用いた。異性 化反応触媒には DABAC 存在下に $\left(\mathrm{Ph}_{3} \mathrm{P}\right){ }_{3} \mathrm{RhCl}$ を使用 し, 同時に 0.015 当量の $\mathrm{Ph}_{3} \mathrm{P}$ を用いることにより触媒 効率が飛躍的に向上し，0.005 当量の触媒による約 1 時 間の反応で定量的な異性化反応を実現した。加水分解に は種々の酸性条件のほかに, 酸化条件を検討したところ, $\mathrm{SeO}_{2} / \mathrm{H}_{2} \mathrm{O}_{2}$ による酸化一加水分解が効果的であった。へ ミアセタール 46 を塩素化してモノマー塩化物 47 を立体 選択的に合成した。

最初のラムノース同士のカップリング反応を熱グリコ シル化反応で達成した。 44 を 1.4 当量の塩化糖 47 およ び 3 当量の $\alpha$-メチルスチレン $(\alpha$-MS $)$ 存在下に, $70^{\circ} \mathrm{C}$ で 15 時間無溶媒に加熱することにより，二量体 48 を $60 \%$ の収率で導いた。ここに用いた $\alpha-\mathrm{MS}$ は酸捕捉剂 であり，先に述べたテトラメチル尿素(TMU)を用いる 場合より遙かに短時間で反応を行うことが可能であっ た。48 のアセチル基を除去してアルコール 49 とし, 再 び47との反応を同様な条件下に行った。かく合成した 三量体 50 をアルカリ加水分解して，アルコール体51 お よび三量体塩化物 52 に導き， $3+3$ の熱グリコシル化反 応を行って六量体 53 を合成した。いずれの熱グリコシ ル化反応においても立体選択性は完全で， $\alpha$-体のみが 生成して $\beta$-体の生成は全く認められなかった。53の両 末端の官能基変換により， $\omega$-ヒドロキシーS-メチル体 54 を導いた。このとき, $\mathrm{SMe}$ 基は $\alpha / \beta 2: 3$ の混合物と して得られた50)。

ここに紹介した六量体合成法は三量体および六量体に ついて，アノマー位の脱保護と活性化官能基の導入とい うステップを必要とするため, 一見合理的に見えるもの の通算収率が非常に不満足なものになった。そこで，モ ノマー塩化物 47 ただ一種類を徹頭徹尾使い切る段階的

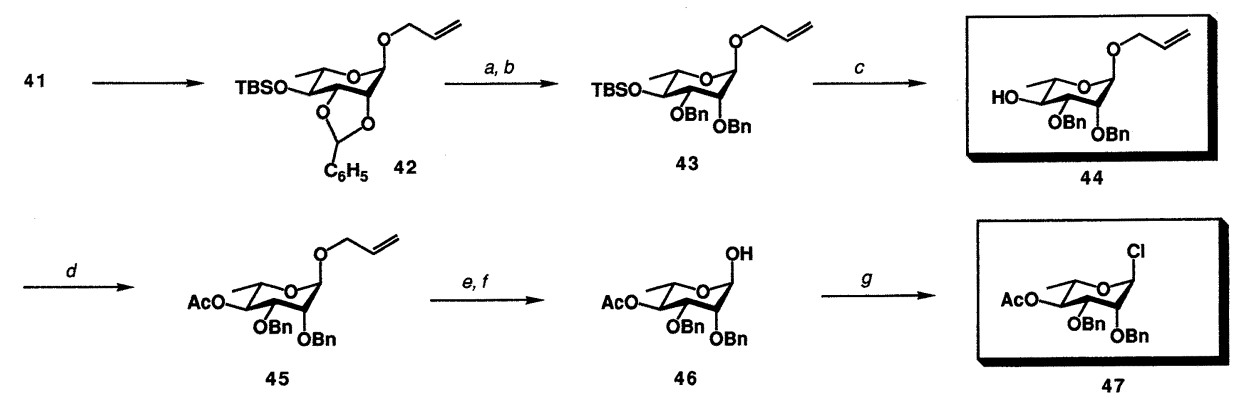

TBS: $t-\mathrm{C}_{4} \mathrm{H}_{9}\left(\mathrm{CH}_{3}\right)_{2} \mathrm{Si}$

a DIBAL/ $\mathrm{CH}_{2} \mathrm{Cl}_{2} \quad b \mathrm{C}_{6} \mathrm{H}_{5} \mathrm{CH}_{2} \mathrm{Br} / \mathrm{NaH} / \mathrm{DMF} / \mathrm{THF}(3: 1) \quad c$ aq HF/CH $/ \mathrm{CH}_{3} \mathrm{CN} \quad d c_{2} \mathrm{O} / \mathrm{C}_{5} \mathrm{H}_{5} \mathrm{~N}$ $e\left(\mathrm{Ph}_{3} \mathrm{P}\right)_{3} \mathrm{RhCl}(0.005 \mathrm{eq}) / \mathrm{Ph}{ }_{3} \mathrm{P}(0.015 \mathrm{eq}) / \mathrm{DABCO}(0.015 \mathrm{eq}) / \mathrm{C}_{2} \mathrm{H}_{5} \mathrm{OH} / \mathrm{C}_{6} \mathrm{H}_{6} / \mathrm{H}_{2} \mathrm{O}(7: 3: 1)$, reflux, $3 \mathrm{~h}$ $f \mathrm{SeO}_{2} / \mathrm{H}_{2} \mathrm{O}_{2} / \mathrm{CH}_{3} \mathrm{CN} / \mathrm{pH} 7$ phosphate buffer $g \mathrm{SOCl}_{2} / \mathrm{CH}_{2} \mathrm{Cl}_{2} / \mathrm{DMF}$

Fig. 11 


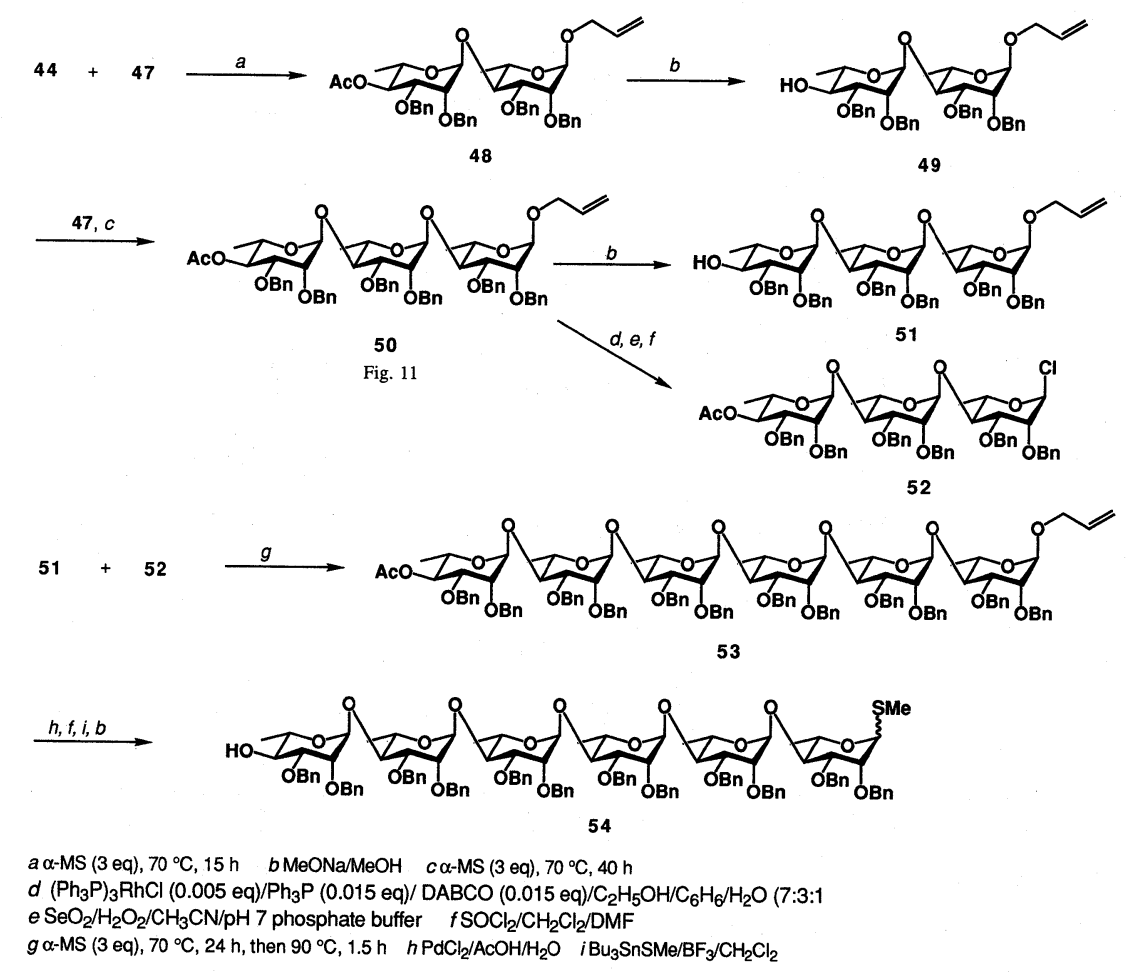

Fig. 12

合成ルートを検討することにした。そして,アノマー位 の保護基に, 最終の環化反応における活性化反応基であ る SMe 基を始めから導入して抢くことを考えた。SMe 基が生存し得るような熱グリコシル化反応条件の設定が 問題となる。47と $\mathrm{Bu}_{3} \mathrm{SnSMe}$ の反応で $\mathrm{SMe}$ 基は容易に 導入できた。アセチル基を除去して得る 56 と 47 の熱グ リコシル化反応は酸捕捉剤が $\alpha-\mathrm{MS}$ では制御できず, 複 雑な混合物を与えてしまったが, TMU を用いて比較的 低温で長時間を費やすことにより高収率で二量体 57 を
得ることができた。以下, 脱アセチル化と 47 /TMUに よる熱グリコシル化を繰り返していく。三量体 59 は 134 時間の反応で $97 \%$ の収率，四量体 60 は 150 時間の 反応で $81 \%$ の収率, 五量体 61 は 153 時間を要して $79 \%$ の収率, そして六量体 62 は 168 時間を費やして 88\%の収率でそれぞれ生成した。各熱グリコシル化反 応において，その立体選択性は $100 \%$ の $\alpha$-選択性であ り, SMe 基の立体化学も全く変化を受けなかった。合 成ルートが遙かに単純化されたこととともに, 本来環化

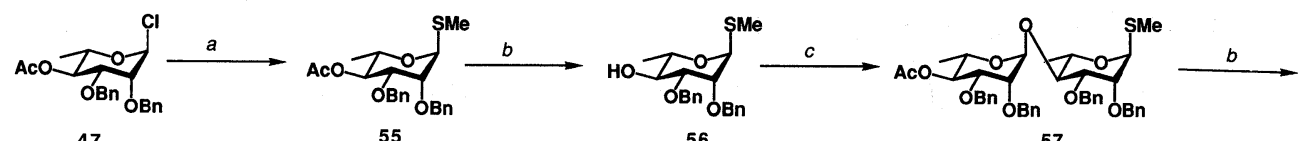

47

55

56

57
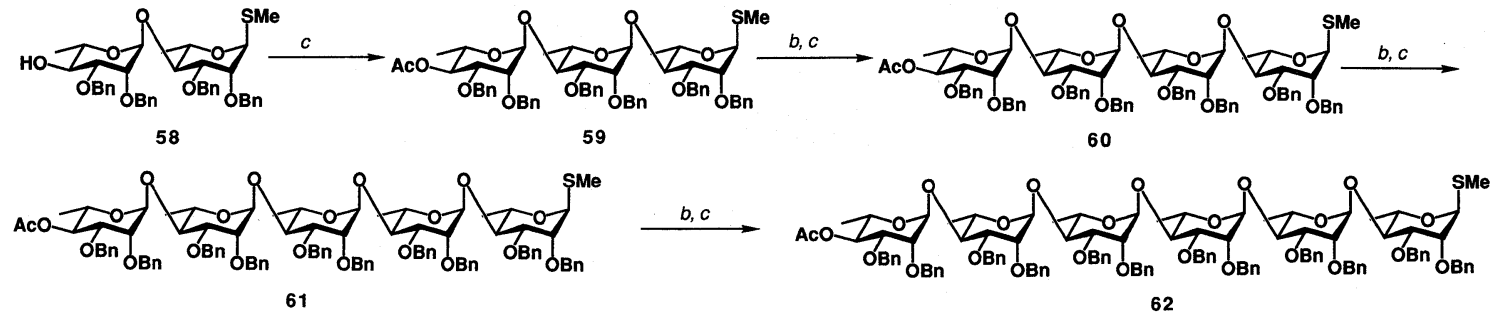

$a \mathrm{Bu}_{3} \mathrm{SnSMe} / \mathrm{BF}_{3} / \mathrm{CH}_{2} \mathrm{Cl}_{2} \quad b \mathrm{MeONa} / \mathrm{MeOH} \quad c 47(2-4 \mathrm{eq}) / \mathrm{MMU}(3-6 \mathrm{eq}), 70-100{ }^{\circ} \mathrm{C}, 24-160 \mathrm{~h}$

Fig. 13 

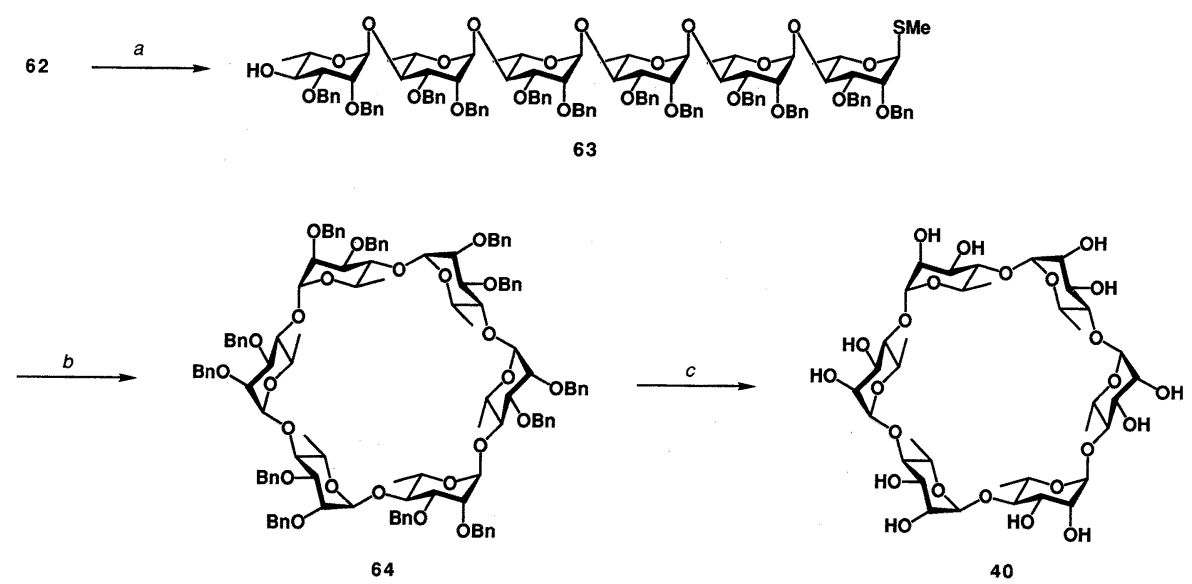

a MeONa/MeOH $\quad b \mathrm{MeSSMe}_{2} \mathrm{OTf}(\mathrm{DMTST}) / \mathrm{CH}_{2} \mathrm{Cl}_{2},-20^{\circ} \mathrm{C}, 10 \mathrm{~h} \quad c \mathrm{H}_{2} / \mathrm{Pd}(\mathrm{OH})_{2} / \mathrm{MeOH} / \mathrm{EtOAC} / \mathrm{H}_{2} \mathrm{O}(12: 1: 1)$

Fig. 14

グリコシル化反応の活性化基である SMe 基が，熱グリ コシル化反応に扔けるアノマー位の保護基としての大役 をこなしきったことが大きく, 先の $3+3$ ルートに比心゙ て，通算収率を 10 倍以上に向上させることができた ${ }^{51)}$ 。

62 を脱アセチル化して得た $\omega^{-}$ヒドロキシーS-メチル 体 63 の環化反応は，始めに小川らが報告している PhSeOTf による活性化法を検討し，23\%の収率で環状 体 64 を得だ0)。さらに, 近年報告された種々のチオグ リコシド基の活性化法を検討し, 塩化メチレン中, 一 $20^{\circ} \mathrm{C}$ で過剩の DMTST (dimethylthiomethylsulfonium tri- flate)と処理する方法で収率を $56 \%$ にまで向上させるこ とができた。鎖状六量体が複雑な NMR を示すのに対し， 64 の NMR は水素, 炭素とも非常にシンプルで, 本質的 にラムノース単糖のそれであった。しかし，64 はマス スペクトルの測定に扔いて親イオンピークを検出できな かったことから，それが真にL-ラムノース環状六量体 であるという明確な証拠を欠いていた。64を $\mathrm{Pd}(\mathrm{OH})_{2}$ を触媒とする水素添加により脱保護して得られた化合物 は，その単純な NMR スペクトルとともに，高分解能 $\mathrm{FAB}$ マススペクトルにより 40 の構造を満足する分子式

${ }^{1} \mathrm{H} \mathrm{NMR}$ of 40 in $\mathrm{D}_{2} \mathrm{O}$ at $80^{\circ} \mathrm{C}(600 \mathrm{MHz})$

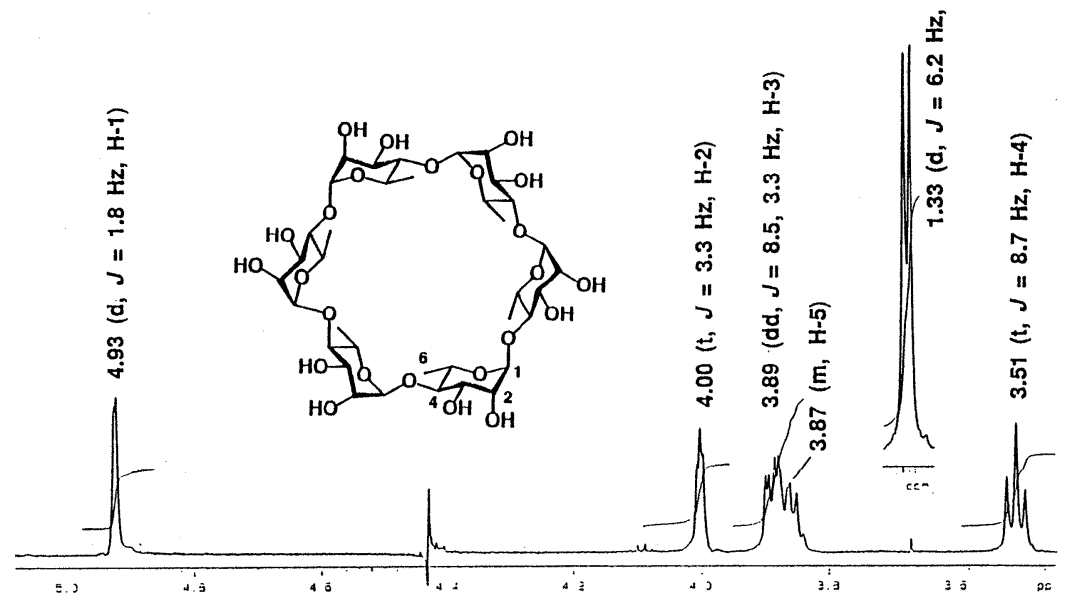

Fig. 15 


\section{${ }^{13} \mathrm{C}$ NMR of 40 in $\mathrm{D}_{2} \mathrm{O}$ at $80^{\circ} \mathrm{C}(150 \mathrm{MHz})$}

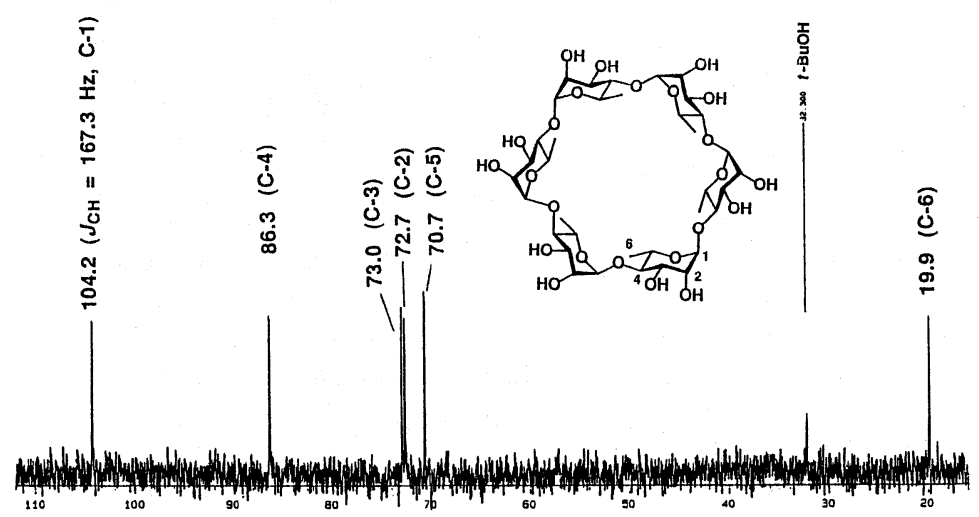

Fig. 16

$\mathrm{C}_{36} \mathrm{H}_{60} \mathrm{O}_{24}$ を確認することができた ${ }^{511}$ 。

初めての $\mathrm{L}$-系列環状オリゴ糖 40 の名称はシクロ-Lラムノヘキサオースであるが，シクロ-Dーグルコヘキサ オース（1）を $\alpha$-シクロデキストリンと呼ぶのに対抗し うるし系列の名称を与えたいと考えた。筆者は植物成 分の研究を経験しており, 少なからぬ天然有機化合物に 原植物に由来する名称を与えてきたが，今回はこの化合 物が生まれた地名を取り, 語呂のよさを考虑して $\alpha$-シ クロアワオドリンと命名することにした。

$\alpha$-シクロアワオドリン $(40)$ の重水中での NMR は室温 で測定するとかなりブロードである。各シグナルの帰属 は簡単であるが, ${ }^{13} \mathrm{C}$ NMR ではとりわけ, C-2 と C-4 が幅広いピークとなる。 $80^{\circ} \mathrm{C}$ にまで昇温して測定する と他のピークと同じ高さのピークとなる。 4 位は ${ }^{~} \mathrm{H}$ NMR では $3.51 \mathrm{ppm}$ と高磁場側に, ${ }^{13} \mathrm{C}$ NMR では 86.3 $\mathrm{ppm}$ と大きく低磁場側にシフトして現れる。アノマー 炭素は $104.2 \mathrm{ppm}$ に $J_{C H}=167.3 \mathrm{~Hz}$ のダブレッドで現 れ，水素は $4.93 \mathrm{ppm} に J=1.8 \mathrm{~Hz}$ のダブレッドとして 観測される。 $\alpha$-シクロアワオドリンのコンフォメーショ ンは当面非常に興味ある課題であるが，40の結晶の作 成に目下努力している。そして， L-系列の特徴を発揮し て新しい包接の化学を展開することを期しているが，そ のためには今一桁合成効率を向上させる必要があり，さ らに努力を続けている。

水と空気と魚の旨いここ徳島の地で, 初めての L-系 列環状オリゴ糖である $\alpha$-シクロアワオドリンの全合成 が達成された。研究はまだほんの端緒についたばかりで あり今後の展開こそ重要であるが，この合成研究に青春 のエネルギーをぶつけて今日までがんばってきた非常に 若い共同研究者諸君, とくに今川 洋, 菅由紀子, 久保
圭子，山田英俊の諸氏に改めて感謝して結びとする。 (平成 5 年 1 月 7 日受理)

\section{文献}

1）小宮山真, 平井英史, “シクロデキストリンの化学” 学会出版センター, 東京, 1979

2) W. Saenger, Angew. Chem.Int.Ed.Engl., 19, 344 (1980)

3) I. Tabushi, Acc. Chem. Res., 15, 66 (1982)

4) 井上義夫, 科学, 55, 710 (1985)

5）小宮山真，平井英史，有合化，44，49 (1986)

6）高橋圭子, 化学と工業, 44, 254 (1991)

7) K. Uekama, F. Hirayama, Chem. Pharm. Bull., 26, 1195 (1978)

8）八ウス食品，日特開，昭 50-101564 (1975)

9) T. Ogawa, Y. Takahashi, Carbohyd. Res., 138, C5 (1985)

10) Y. Takahashi, T. Ogawa, ibid., 164, 277 (1987)

11) idem, ibid., 169, 127 (1987)

12) M. Mori, Y. Ito, T. Ogawa, Tetrahedron Lett., 30, $1273(1989)$

13) M. Mori, Y. Ito, J. Uzawa, T. Ogawa, Tetrahedron Lett., 31, 3191 (1990)

14) M. Mori, Y. Ito, T. Ogawa, ibid ., 31, 3029 (1990)

15) P.M. Collins, A. Manro, E.C. Opara-Mottah, M.H. Ali, J. Chem. Soc., Chem. Commun., 1988, 272

16) P.M. Collins, M.H. Ali, Tetrahedron Lett., 31, 4517 (1990)

17) S. Cottaz, H. Driguez, J. Chem. Soc., Chem. Commun., 1989, 1088

18) N. Sakairi, L.X. Wang, H. Kuzuhara, ibid., 1991, 289

19) A. Gradella, J. Defaye, Angew. Chem. Int. Ed. Engl., 30, 78 (1991) 
20) P.R. Ashton, P. Ellwood, I. Staton, J.F. Stoddart, ibid., 30, 80 (1991)

21) W. Koenigs, E. Knorr, Ber., 34, 957 (1901)

22) S. Hanessian, J. Banoub, Carbohydr. Res ., 53, C13 (1977)

23) T. Mukaiyama, Y. Murai, S. Shoda, Chem . Lett., 1981, 431

24) R.R. Schmidt, G. Grundler, Angew. Chem. Int. Ed. Engl., 19, 885 (1981)

25) Y. Ito, T. Ogawa, Tetrahedron Lett., 29, 1061 (1988)

26) S. Hashimoto, M. Hayashi, R. Noyori, ibid ., 25, 1379 (1984)

27) T. Matsumoto, H. Maeta, K. Suzuki, G. Tsuchihashi, ibid., 29, 3567 (1988)

28) D. R. Mootoo, P. Konradsson, U. Udodong, B. Fraser-Reid, J. Am. Chem. Soc ., 110, 5583 (1988)

29) K.C. Nicolaou, S.P. Seitz, D.P. Papahatjis, ibid., $105,2430(1983)$

30) S. Hashimoto, T. Honda, S. Ikegami, Tetrahedron Lett. , 31, 4769 (1990)

31) D. Kahne, S. Walker, Y. Cheng, D. Van Engen, J. Am. Chem. Soc., 111, 6881 (1989)

32) R.L. Halcomb, S.J. Danishefski, ibid ., 111, 6661 (1989)

33) R.W. Friesen, S.J. Danishefski, ibid ., 111, 6656 (1989)

34) M.J. Ford, S.V. Ley, SYNLETT, 1990, 255

35) K. Koide, M. Ohno, S. Kobayashi, Tetrahedron
Lett . , 32, 7065 (1991)

36）橋本俊一, 池上四郎, ファルマシァ, 27, 50 (1991)

37）鈴木啓介，長澤徹哉，有合化，50，378 (1992)

38）伊藤幸成, 小川智也，第 4 版実験化学講座 26 , 有 機合成VIII, 不斉合成, 還元, 糖, 標識化合物, 丸善, 東京, pp.267 354, 1992

39) M. Nishizawa, H. Yamada, Y. Hayashi, Tetraheron Lett., 27, 3255 (1986)

40) idem, J. Org. Chem., 52, 4878 (1987)

41) H. Yamada, M. Nishizawa, Tetrahedron Lett ., 28, 4315 (1987)

42）西沢麦夫, 山田英俊, 化学増刊, 114, 151 (1988)

43) H. Yamada, M. Nishizawa, Tetrahedron, 48, 3021 (1992)

44) H. Yamada, M. Nishizawa, C. Katayama, Tetrahedron Lett., 33, 4009 (1992)

45) H. Yamada, M. Nishizawa, SYNLETT, 1993, 54

46) M. Nishizawa, Y. Kan, H. Yamada, Tetrahedron Lett., 29, 4597 (1988)

47) idem, Chem. Pharm. Bull., 37, 565 (1989)

48) M. Nishizawa, Y. Kan, W. Shimomoto, H. Yamada, Tetrahedron Lett. , 31, 2431 (1990)

49) M. Nishizawa, W. Shimomoto, F. Momii, H. Yamada, ibid. , 33, 1907 (1992)

50) M. Nishizawa, H. Imagawa, Y. Kan, H. Yamada, ibid. , 32, 5551 (1991)

51) M. Nishizawa, H. Imagawa, K. Kubo, Y. Kan, H. Yamada, SYNLETT, 1992, 447

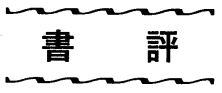

\section{モレキュラー・キラリティー 高次機能分子の開拓と創薬への展開をめざして}

本書では, 時代のキーワードとしての“キラリティー” にまつわる研究の動向について, 実に多様な視点から解 説が加えられている。構成としては 4 章からなって扔り （1 章：キラリティー発生の謎を解く，2 章：キラル識別 のメカニズムを追う， 3 章：キラル識別, 誘導に高分子, 複合系を使う， 4 章：キラル薬物の体内動態を探る), 各章の題名からも分かるように, キラリティーの自然発 生，分子認識などの基礎的興味をそそる内容に始まり， マテリアルサイエンス，医薬品の分野における応用的内 容に至るまで広くカバーされており，読みごたえがある。
原昭二・古賀憲司・首藤紘一／編 化学同人 175 ページ;定価 3,708 円 